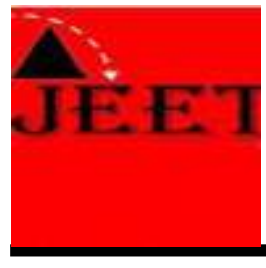

\title{
Students' Perspective on Project-Based Assessment in Writing Classroom
}

\author{
Amalul Umam \\ Universitas Ibn Khaldun \\ amalul.umam@uika-bogor.ac.id \\ Tiwi Handini \\ Universitas Ibn Khaldun \\ tiwihandini11@gmail.com
}

Corresponding email: amalul.umam@vika-bogor.ac.id

\begin{abstract}
Project based assessment is one of the techniques that are suggested to be used by ELT Practitioners due to its effectiveness. Its implications in EFL classrooms have been studied by many scholars. Little is done in the perspective of the students' point of view. This study aimed to examine students' perspectives at the university level regarding project-based assessment in a writing class. The study is framed under qualitative approach in which interviews and documentation are used as data collections. The interview is done individually, and the data collected from interview has been re-cross checked to the participants to make sure that all of the data are valid. This research is conducted at one of universities in Bogor city. Participants in the study consist of eight female students who have experienced in having projectbased assessment during their study. The participants were selected based on their voluntary wills in contributing in the study. The findings show that some students' reveal that project-based assessment is not easy to do. It is said that project-based assessment can add experience in terms of writing, even though it takes a long time to complete. There are some benefits of project-based assessment, honing writing skills, enabling students in selecting information, and solving problems faced by students.
\end{abstract}

Keywords: Project-Based assessment, students' perspective, writing as assessment.

\section{Introduction}

In Indonesia, writing is one of the complicated skills for students at the level of education, ranging from low to high, as stated by Murtadho (2021). Levy (1995) also said that writing is a tricky activity and has many procedures, so not many students are reluctant to do it. By looking at the phenomenon, writing activities need to be taught as best as possible or even maximized, as Murtadho (2021) expressed, who proposed that writing is critical in developing and channeling ideas that want to convey verbally. 
One of the suggested methods to make the learning process effective is using project-based learning. It believes in this method can stimulate students' learning. In turn, the assessment will also adapt to which project-based assessment can apply. According to Doppelt (2005), project-based assessment aims to learn and provide materials to students. Besides, the assessment itself also has much influence on learning in the classroom, such as testing students' creative thinking skills (Doppelt, 2005); students' critical abilities (Hawe \& Parr, 2014); measuring student competence (Kamalia and Srisudarso, 2020); the student's ability to assess the process, determine the purpose for himself or herself (Brown, 2004) and so on.

In Indonesia, in carrying out assessments, it is recommended to use authentic assessment in its curriculum, namely the 2013 curriculum as described by Natalia et al. (2018), which corresponds to Indonesian ministry of education and culture regulations No. 23 of 2016, assessment as a process in the collection of data in detail based on behavior, knowledge, ability, and development in the following learning in school. In this assessment, the teacher plays the role of an assessor in the development of the students. Besides, Natalia et al. (2018) also describe the Indonesian ministry of education and culture regulations. No. 104 of 2014 on authentic assessment requires students to develop through behavior, knowledge, and abilities based on actual learning situations in schools. Brown (2004) added that authenticity is a real-world assessment. In reality, some studies show that teachers have problems in assessing their students due to their low level of assessment literacy (Umam \& Indah, 2020), even though some academicians have tried to introduce an authentic assessment to teachers' candidate during their study (Jaelani \& Umam, 2021).

One of the authentic-assessment is a project-based assessment. The projectbased assessment also has benefits such as shaping students' ability to assess others and also be able to assess the process students working on (Hanardi, 2015); assist students in finding solutions, improving their knowledge and abilities (Goosen \& Heerden, 2013); use their academic knowledge in their daily lives and application requires students to demonstrate the actions (Arlinawati et al. 2017).

Some research also focuses on implementing project-based assessments, such as Goosen and Heerden's (2013) application of project-based assessment through ICT (Information Communication Technology) in Open Distance Learning Institutions to improve learning and teaching computer programming. Natalia, Asib, 
and Kristina (2018) investigate the influence of assessment through students' writing skills in English learning. Van den Bergh et al. (2006) also conducted similar research to explore the perspectives of students and teachers who apply project-based learning. Arlinawati et al. (2017) implemented project-based assessments in business communication to make it easier for teachers to conduct authentic project-based assessments of student processes and learning. Hanardi (2015) also researched project-based assessment to develop alternative learning models based on assessment projects following the application of the 2013 curriculum.

\section{Students' Perspective}

Perspective is a point of view, or it can also be the way to describe something based on what we see and feel. Nguyen and Filipi (2018) explain that in learning about a student's perspective, perspective in asking students' opinions about feedback from students from teachers and opinions about peers. Nguyen and Filipi (2018) also added that a large number of studies with the results of several language learner students are very fond of the feedback that teachers give directly or indirectly with examples, such as with the feedback students can understand where their mistakes in doing an assignment ( quoted in the Nguyen and Filipi (2018) from Chandler (2003)).

\section{Academic Writing}

According to Bybee et al. (2009), academic writing is a term used in expressing a purpose in education more broadly and enjoyable to read. Oshima Ann Hogue et al. (2007) also describes writing as activities performed by students at the higher or secondary education level. Academic writing is writing that uses formal language and requires organizing in doing its writing. Academic writing in English is undoubtedly very different if compared with academic writing in our native language is due to grammar and words also formed how the author found ideas in doing the writing. In writing, the author must include or insert outside-sourced information or citations. Academic writing is beneficial, especially in developing or even adding smoothness in writing and giving writers opportunities to develop existing ideas into writing.

\section{Project-based assessment}


O'Malley and Pierce (1996), as quoted in Rukmini (2017), described three types in authentic assessment: performance assessment, portfolios, and students-self assessment. Based on the description above, the 2013 curriculum also applied the above three things in the learning. In the legislation - ministry of education and culture of Indonesia in 2013, number 81 a explained that performance assessment by observing all activities of students; portfolio assessment is evidence that students have done their duties and as a process of students in conducting their learning (Rukmini, 2017).

Hanardi (2015) explains what needs in Project-Based Learning or PBL is writing, making observations, self-assessment, or even peer-assessment and reciprocity from teachers. As cited by Hanardi (2015) from McDonald (2018) also added some discussions related to assessment, such as model and its learning models, which have the purpose of mentoring students in do the work. Also suggesting that an effective and good learning tool can also come from the assessment itself as know that the purpose of the assessment is to make students further develop their ideas in learning and achieve the best results based on their ability.

\section{Research Methodology}

The study is framed under qualitative approach. According to Jackson et al. (2007) qualitative research focuses on discussions that understand the experiences in humans through humanist and interpretive approaches. This study uses two ways in collecting data, namely, interviews and documentation.

Participants are chosen based on some criteria, such as their voluntary will to participate in the study, their experience of finishing a project-based assessment and their understanding of project-based assessment. After those mentioned criteria before were applied, there are eight female students aged between 20-25 years old who are eligible as respondents. These eight students are listed as students of an English language education department who have been carrying out the activities of the study for three years and have written an academic article as their projects.

For the data collection itself, researchers use interviews and documentation. According to Griffee (2005), the interview is a relatively popular way of collecting qualitative research data because it is considered a regular chat between the interviewer and the interviewer who does not bring up statistical knowledge. The respondent will feel close to the researcher. According to Creswell (2009), 
documentation is a way to collect data in qualitative research and assist researchers in understanding the problems in their research. For interviews it is conducted online using WhatsApp. There are five main questions in the interviews. For documentation, researchers have collected the participants' writings in the form of academic articles.

In analyzing the data, the researchers applied the theory of Jackson et al. (2007), which suggests that all activities in qualitative data analysis are conducted interactively and continue continuously until complete. Activities carried out in the analysis include data reduction, data display as well as taking conclusion.

\section{Findings and Discussion,}

\section{Findings}

The findings of the study can be classified into two big themes, positive and negative perspectives. It is said to be positive because it can scaffold students' understanding about the world out there and excel their writing skills especially in helping them to comprehend reading materials faster and strengthen their critical thinking. These positive perspectives can be seen from the following excerpts.

"....so, we have writing activities. We come to know the world of writing because actually what I know before entering the world of writing academic articles are only about writing short stories, poems, novels. It turns out that there is scientific writing like that, and I know when I get a course and start writing ......" (Excerpt 1)

".... writing academic article is very useful for honing my writing skills from which I can read faster, train my critical thinking, and also practice language skills." (Excerpt 2)

From the excerpt 1, the respondent initially has no idea about the existence of academic articles that are published in some journals all over the world. By having experience of completing project-based assessment, she knows about academic articles. This knowledge is certainly beneficial for the future of respondent, especially in academic life. It is supported by the excerpt 2 that illustrates the benefits. We can derive that project-based assessment helps respondents in improving their English skills, especially in reading comprehension. In addition, writing skills and critical thinking are also scaffolded during the progress of completing the project given. 
In contrast, there are some negative perspectives found during this study. The list are time limitation, challenging, and less motivated. These reasons can be visualized through the following excerpts.

".... Obstacles that I faced (in completing the project) is lack of free time so that the process of completion is increasingly stretched, ... it takes time for getting response (collecting data needed)...."( Excerpt 3)

From the excerpt 3 above, it is obvious that the respondent has many responsibilities that makes her unfocused to work on the project. She admitted that the time for completing the project is not enough, especially in collecting the data. As a result, the project is seen as something that is quite challenging to be completed. It is supported by the following excerpt.

".... looking for the source (navigating sources) that matches the title to be created (as academic) article...." (Excerpt 4)

The excerpt 4 reveals that the respondent has some problems in finding out the right materials or sources to complete the project given. It gives some burden for the respondent due to the limited time that is available. So, it is seen as a hard task to complete. As a result, the project, to some extent, demotivated some respondents. It can be seen from the following excerpt

"...(I feel) lazy sometimes. Honestly, my reading literacy is low. When I will write my new article, I must read. When I have to read for hours to make honest (original) academic article, I am lazy to read and that makes me read less...." (Excerpt 5)

The excerpt 5 proves, for some respondents, that the project requires a lot of effort to complete. It affects the motivation of the respondents, especially for those with low self-esteem. The project makes the students with low self esteem decrease their motivation in learning.

\section{Discussion}

To find out students' perspectives about project-based assessment in writing classes at the university level, researchers used interviews and documentation to eight participants. The study found positive and negative responses from the participants about project-based assessment in writing class. 
After implementing the project-based assessment, students felt that they have some problems, such as limited time given. It is in line with the explanation that Messick (1996) explained that authentic assessment is ideally an exciting task because it requires a process in it and time in its design. Furthermore, Zhao (2017) reveals that the difficulties students face when writing in English, especially in time, make students feel like they have nothing. Besides, Hassan et al. (2021) also explain that managing time is crucial, as we know that each person has the same portion of time. The second problem faced is finding article materials used as reference material, as confirmed by Al-Badi (2015); who proposed that finding sources is difficult for the first time trying to write. As Gülbahar and Tinmaz (2006) study, workable solutions are another way to do this is to search the internet and visit the library, after which students can compose the writing they will make. Al-Badi (2015) also added that students sometimes do not have adequate foundation data about the issue they are expounding on. The third problem is the lazy-ness of reading when writing a workable solution is to read more articles, books, or sources from the internet. As revealed by Phakiti \& Li (2011), reading and writing is an activity that has reciprocity between each other because reading can get ideas to write, and then writing can make students read to look for ideas for the writing that will do.

After completing Project-Based Assessment, students have different responses about project based-assessment such as writing is not easy; it is also in accordance with Umamah and Cahyono (2020) quoted from Ferretti \& Graham (2019) that writing is a challenging process for students because writing is quite tricky in developing a sentence into an essay. Schleppegrell and Go (2007) also added that writing is difficult, especially for those who are just starting to learn as they express their ideas. Furthermore, Al-Badi (2015) confirmed that academic composing could be a mind-boggling measure. It includes an assortment of angles that are accepted to be the basis of fruitful scholarly composition. Then, the next student's response about project-based assessment is to add experience in writing an article this agrees with the Phakiti and Li (2011), which states that by writing, students will have experience learning from the problems and benefits that occur during the process to make students more able to adjust to new things. The subsequent response is that writing takes a while to work on it, and Phakiti and Li (2011) also supported the time required in its design can also affect solving the problems students face. Levy (1995) 
also added that completing a piece of writing requires a sufficient allocation of time, and it will affect the quality of the writing.

Here are the benefits that students get in applying project-based assessment in writing classes, which can be said to be a positive perspective. Students have some activities and get to know the world of writing better; participants become more active after getting to know the world of writing and become better at writing as stated by Levy (1995) that writing is one of the ongoing activities that we can be doing when we want to do it. Writing is also one way to fill free time with many benefits to be had. The next benefit that students get is to hone their writing skills. Yi supports it (2009) by stating that writing can create something coherent with a specific pattern used in developing. Another benefit is, being selective in any receiving information. Writing can make students have critical thinking expressed by Murtadho (2021). In choosing the writing materials used as a reference, students will choose which one is appropriate to use as a reference.

\section{Conclusion and Suggestion}

Project-based assessment is one of the efforts to improve students' willingness and ability in some issues. This study aims at examining student perspectives about project-based assessment in writing classes. The results show that the application of project-based assessment in writing an article journal has various essential benefits for students (Shirzadi and Amerian ,2020). The benefits included practicing writing skills, critical thinking, making it easier to write the following article, and many more. Writing students can also judge their perspectives process of writing as said by Wong and Mak (2019), which is also influential student learning project-based behind it. Then, writing can also be used as a reference for assessing students' learning.

\section{References}

Al-Badi, I. A. H. (2015). Academic writing difficulties of ESL learners. ResearchGate, August, 63-76.

Arlinawati, Indah Putri; Hermawan, Agus; Chodryah, L. (2017). Development of Project-Based Authentic Assessment Instruments On Business Communication Subjects. Jurnal Pendidikan Bisnis Dan Manajemen, 3(1), 46-54.

Brown, D. H. (2004). Language Testing Book: Principles and Classroom Practice. In Longman. Longman.

Bybee, R., McCrae, B., \& Laurie, R. (2009). PISA 2006: An assessment of scientific 
literacy. Journal of Research in Science Teaching, 46 (8), 865-883.

Creswell, W. J. (2009). Research Design (Third Edition). California: SAGE Publication.

Doppelt, Y. (2005). Assessment of Project-Based Learning in a MECHATRONICS

Context. Journal of Technology Education, 16(2).

Goosen, L., \& Heerden, D. Van. (2013). Project-Based Assessment Influencing Pass

Rates of an ICT Module at an ODL Institution. ResearchGate, November 2018.

Griffee, D. T. (2005). Research Tips: Interview Data Collection Issues and Decisions. Journal of Developmental Education, 28(3), 36-37.

Gülbahar, Y., \& Tinmaz, H. (2006). Implementing Project-Based Learning And E-

Portfolio Assessment In an Undergraduate Course. Journal of Research on Technology in Education, 5191, 309-327.

Hanardi, L. G. (2015). A Project-Based Assessment Model of English for Senior High

School Grade X. Indonesian Journal of English Language Studies, 1 (1), 70-92.

Hassan, N., Zubir, H. A., Akmal, M., Mohzan, M., Halil, A., \& Jamil, M. (2021). Washback

On Learning: The Experience Of Outcome-Based Assessment In A Higher Learning Institution In Malaysia. PalArch's Journal of Archaeology of Egypt/ Egyptology, 18(4), 3408-3425.

Hawe, E., \& Parr, J. (2014). Assessment for Learning in the writing classroom: An incomplete realization. Curriculum Journal, 25(2), 210-237.

Jackson, R. L., Drummond, D. K., \& Camara, S. (2007). What is qualitative research? Qualitative Research Reports in Communication, 8(1), 21-28.

Jaelani, A., \& Umam, A. (2021). Preparing EFL pre-service teachers for curriculum 2013 through authentic materials and assessment integration. Journal of English Educators Society, 6(1). https://doi.org/10.21070/jees.v6i1.829

Kamalia Hakim, P., \& Srisudarso, M. (2020). A Washback Study on Portfolio Assessment. ELT in Focus, 3(1), 9-14. https://doi.org/10.35706/eltinfc.v3il.3693

Levy, C. M. (1995). Is writing as difficult as it seems? Psychonomic Society, Inc., 23(6), 767-779.

Messick, S. (1996). Validity and washback in language testing. Language Testing, 13(3), 241-256. https://doi.org/10.1177/026553229601300302

Murtadho, F. (2021). Metacognitive and critical thinking practices in developing EFL students ' argumentative writing skills. Indonesian Journal of Applied Linguistics, $10(3), 656-666$.

Natalia, D. E., Asib, A., \& Kristina, D. (2018). The Application of Authentic Assessment 
for Students Writing Skill. Journal of Education and Human Development, 7(2), 49-53. https://doi.org/10.15640/jehd.v7n2a5

Nguyen, H., \& Filipi, A. (2018). Multiple-Draft/Multiple-Party Feedback Practices in an EFL Tertiary Writing Course: Teachers' and Students' Perspectives. International Education Studies, 11 (8), 1. https://doi.org/10.5539/ies.v1 ln8pl

Oshima Ann Hogue, A., Carlson, E., DiLillo, G., Edmonds, C., Le Drean, Linda Moser, L., \& Pullman, E. (2007). Introduction to Academic Writing THIRD EDITION. In Pearson Education Limited.

Phakiti, A., \& Li, L. (2011). General academic difficulties and reading and writing difficulties among Asian ESL postgraduate students in TESOL at an Australian University. RELC Journal, 42(3), 227-264.

Rukmini, D. (2017). The Authentic Assessment To Measure Students ' English Productive Skills Based On 2013 Curriculum. Indonesian Journal of Applied Linguistics, 7(2), 263-273.

Schleppegrell, M. J., \& Go, A. L. (2007). Analyzing the Writing of English Learners: A Functional Approach. Language Arts, 84(6), 529-538.

Shirzadi, D., \& Amerian, M. (2020). Washback effects of multiple-choice, cloze, and metalinguistic tests on EFL students writing. Indonesian Journal of Applied Linguistics, 9(3), 536-544. https://doi.org/10.17509/ijal.v9i3.23203

Umam, A., \& Indah, Y. A. (2020). Exploring In-Service TEYL Teachers ' Assessment Literacy: Implication for Continuing Professional. Journal of English Educators Society, 5(1), 47-51.

Umamah, A., \& Cahyono, B. Y. (2020). Indonesian university students ' self-regulated writing ( SRW ) strategies in writing expository essays. Indonesian Journal of Applied Linguistics, 10(1), 25-35.

Van den Bergh, V., Mortelmans, D., Spooren, P., Van Petegem, P., Gijbels, D., \& Vanthournout, G. (2006). New Assessment Modes Within Project-Based Education - the Stakeholders. Studies in Educational Evaluation, 32 (4), 345-368.

Wong, K. M., \& Mak, P. (2019). Self-assessment in the primary L2 writing classroom. Canadian Modern Language Review, 75(2), 183-196.

Yi, J. (2009). Defining Writing Ability for Classroom Writing Assessment in High Schools. Pan-Pacific Association of Applied Linguistics, 13(1), 53-69.

Zhao, J. (2017). Native speaker advantage in academic writing? Conjunctive realizations in EAP writing by four groups of writers. Ampersand, 4, 47-57. 